
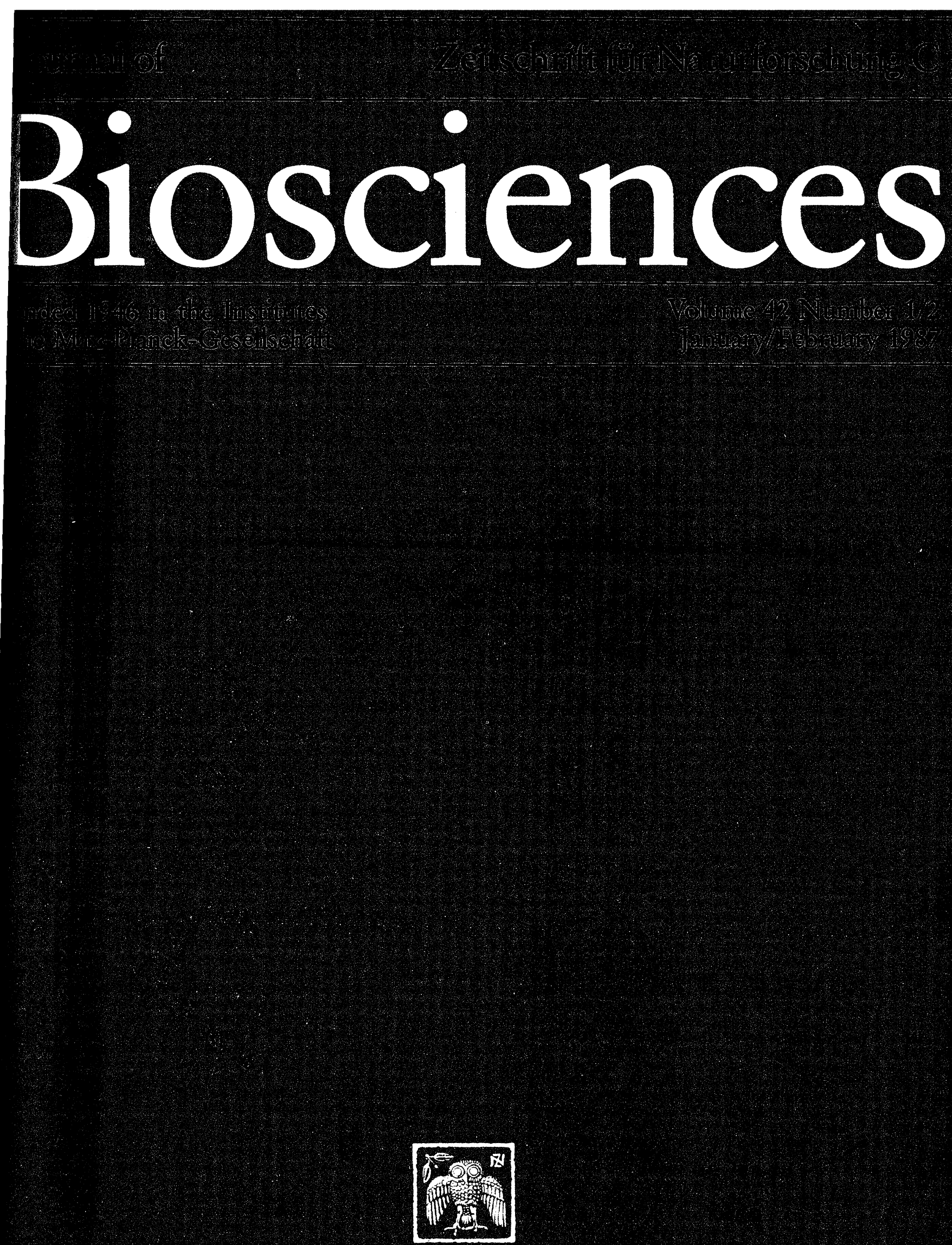


\section{ZEITSCHRIFT FÜR NATURFORSCHUNG}

Section $\mathrm{C}$

A Journal of Biosciences

ISSN 0341-0382

Managing Editor:

H. Hausen, Tübingen

Council:

E. Bünning, Tübingen

A. Butenandt, München

M. Eigen, Göttingen

Editors:

A. Hager, Tübingen

K. Hahlbrock, Köln

W. Hasselbach, Heidelberg

P. Karlson, Marburg

F. Kaudewitz, München

J. Klein, Tübingen

J. St. Schell, Köln

E. Wecker, Würzburg

\section{Associate Editors:}

N. Amrhein, Bochum

B. A. Askonas, London

W. Barz, Münster

P. Böger, Konstanz

G. Bornkamm, Freiburg

D. Bückmann, Ulm

K. G. Götz, Tübingen

G. Gottschalk, Göttingen

P. Gruss, Heidelberg

G. Isenberg, Köln

R. Jaenicke, Regensburg

V. ter Meulen, Würzburg

G. F. Meyer, Tübingen

M. Rajewsky, Essen

H. Schimassek, Heidelberg

D. Schulte-Frohlinde, Mühlheim/R.

G. Schulz, Freiburg

F. F. Seelig, Tübingen

J. Seelig, Basel

H. Simon, München

W. Steglich, Bonn

H. Stieve, Aachen

J. Suko, Wien

A. Trebst, Bochum

G. Weissenböck, Köln

G. Wick, Innsbruck

V. Zimmermann, Würzburg

\section{Information for Contributors}

Contributions to Z. Naturforsch., Section C (biological sciences), may be (i) original papers, (ii) research notes not exceeding two pages in print and (iii) reports on current research of special interest. Two copies of each contribution should be sent to Dr. Helga Hausen, P. O. Box 2645, D-7400 Tübingen. (Section B (chemical sciences): Dr. Heide Voelter, P.O. Box 2645, D-7400 Tübingen; Section A (physical sciences): Mrs. Tamara Littmann, Lenzhalde 21, D-7082 Oberkochen).

Contributors are encouraged to suggest possible reviewers of their papers. The manuscript should be type written using double spacing throughout.

The title should be concise but informative. The names of the authors, with first names and initials, and of the institution where the work was carried out follow the title. A running title with not more than 60 characters should be indicated if the title is longer than this.

In a footnote on the first page, please give an address for reprint requests.

The title, a selfconsistant abstract, suitable for direct use by the abstracting journals (no references to the main text), and five keywords, all in English, must precede the main text of each contribution.

The main text should meet the highest standards as to novelty of the material, organization and conciseness. A qualified colleague and, if the text is in a foreign language, a person who thoroughly knows it, should have been given the opportunity to check the paper before its submission for publication.

Papers, reporting mainly spectroscopic, X-ray or other data of no general relevancy should not be submitted.

References and footnotes should be numbered (e.g. [1]) and listed at the end of the paper (e.g. [1] A. Meyer, Z. Naturforsch. 30 c, 633 (1976)).

Tables with the appropriate captions and a list of the figure legends should follow at the end of the paper.

Allowance should be made for the reduction in printing of the drawings (line thickness, lettering!). Original drawings larger than $21 \times 30 \mathrm{~cm}$ should be replaced by copies of reduced size, when the manuscript is submitted and only be sent in when the manuscript is accepted. On all illustrations, the figure number and the author's name must he written in pencil.

The authors will receive page proofs.

Changes in the text after acceptance of the paper and drawings not fit for direct reproduction cause delay and create extra costs which may be charged to the author. 50 reprints are free of charge.

\section{Information for Subscribers}

The subscription prices per year are for normal subscribers:

$\begin{array}{lll}\text { Section A } & \text { Section B } & \text { Section C } \\ \text { DM 510.- } & \text { DM 610.- } & \text { DM 425.- }\end{array}$

for authors and their institutions if they order directly from the publishers:

Section A Section B Section C

DM 408. - DM 488.- $\quad$ DM 340.-

plus postage and handling

$\begin{array}{lll}\text { Section A } & \text { Section B } & \text { Section C } \\ \text { DM 35.- } & \text { DM 35.- } & \text { DM 25.- }\end{array}$

Single copies and back-numbers are available.

Subscriptions will remain standing for the following year unless cancellations are made by postage October 1st.

\section{Informations for Advertisers}

The price for a small advertisement (breadth $43 \mathrm{~mm}$, height $57 \mathrm{~mm}$ ) in all three sections of the journal is DM 60.-.

For larger advertisments please order the price list from the publishers.

VERLAG DER ZEITSCHRIFT FÜR NATURFORSCHUNG, TÜBINGEN

P. O. Box 2645, D-7400 Tübingen (Postscheck-Konto Stuttgart 8039-700). 


\section{ZEITSCHRIFT FÜR}

\section{NATURFORSCHUNG}

\section{SECTION C}

\section{A EUROPEAN JOURNAL OF \\ BIOSCIENCES}

Council

E. BÜNNING,Tübingen

A. ButenandT, München

M. EIGEN, Göttingen
Editorial Board

A. HAGER, Tübingen

K. HAHLBROCK, Köln

W. HASSELBACH, Heidelberg

P. KARLSON, Marburg

F. KAUdewitz, München

J. KLEIN, Tübingen

J. St. SCHELl, Köln

E. WeCKER, Würzburg

Advisory Editorial Board

N. Amrhein, Bochum

B. A. Askonas, London

W. BARZ, Münster

P. BöGER, Konstanz

G. BoRnKAMm, Freiburg

D. BÜCKMANN, Ulm

K. G. Görz, Tübingen

G. GorTschalK, Göttingen

P. GRuss, Heidelberg
G. IsENBERG, Köln

R. JAENICKE, Regensburg

V. TER Meulen, Würzburg

G. F. MEYER, Tübingen

M. RAJEWSKY, Essen

H. SCHIMASSEK, Heidelberg

D. Schulte-Frohlinde, Mühlheim/R.

G. SCHULZ, Freiburg

F. F. SeElig, Tübingen
J. Seelig, Basel

H. Simon, München

W. STEGLich, Bonn

H. Stieve, Aachen

J. Suko, Wien

A. Trebst, Bochum

G. WEISSENBöcK, Köln

G. WICK, Innsbruck

V. ZimmermanN, Würzburg

EDITED IN COLLABORATION

WITH THE INSTITUTES OF THE MAX-PLANCK-GESELLSCHAFT

\section{VERLAG DER ZEITSCHRIFT FÜR NATURFORSCHUNG TÜBINGEN}


Anschrift des Verlages: Postfach 26 45. D-7400 Tübingen Satz und Druck: Allgäuer Zeitungsverlag GmbH, Kempten

Nachdruck - auch auszugsweise - nur mit schriftlicher Genehmigung des Verlages

Section a

Physics, Physical Chemistry, Cosmic Physics

Section b

Inorganic and Organic Chemistry 


\section{Contents of Number $7 / 8$}

\section{Original Communications}

ZZE-Configuration of Chromophore $\beta-153$ in CPhycocyanin from Mastigocladus laminosus

G. Schmidt, S. Siebzehnrübl, R. Fischer, W. Rüdiger, H. ScheEr, T. Schirmer, W. Bode, and R. Huber

845

$\alpha$-Diceroptene: A New Dimeric Structure for Isoceroptene

Ch. Vilain, A. Hubert, L. Dupont, K. R. MarkHAM, and E. WOLLENWEBER

849

Stereochemistry of Two Hydroxybiflavanonols from Garcinia cola Nuts

J. Sonnenbichler, I. Madubunyi, and H. Scheer

"Epicuticular Waxes" from Exine Material of Pine Pollen

Ch. Niester, P.-G. Gülz, and R. Wiermann 858

Bryoflavone and Heterobryoflavone. Two New Isoflavone-flavone Dimers from Bryum capillare H. Geiger, W. Stein, R. Mues, and H. D. ZinsMEISTER

863

Site of Lupanine and Sparteine Biosynthesis in Intact Plants and in vitro Organ Cultures

M. WINK

868

Occurrence of Amavadin in Mushrooms of the Genus Amanita (In German)

E. Koch, H. KNeifel, and E. Bayer

Ascorbic Acid and Glutathione Contents of Spruce Needles from Different Locations in Bavaria W. F. Osswald, H. Senger, and F. E. Elstner

Acetyl-CoA:4-Hydroxybutinylbithiophene O-Acetyltransferase Isoenzymes from Tagetes patula Seedlings

G. Metschulat and R. Sütfeld

885

Uptake and Utilization of Sulfonic Acids in the Cyanobacterial Strains Anabaena variabilis and Plectonema 73110

S. Biedlingmaier and A. Schmidt
Partial Characterization of an Enzyme from the Fungus Ascochyta rabiei for the Reductive Cleavage of Pterocarpan Phytoalexins to 2'-Hydroxyisoflavans

B. HöHL and W. BARZ

Comparing Short-Term Effects of Ammonia and Methylamine on Nitrogenase Activity in Anabaena variabilis (ATCC 29413)

S. Reich, H. Almon, and P. Böger

902

Reversible pH-Induced Dissociation of Glucose Dehydrogenase from Bacillus megaterium. II. Kinetics and Mechanism

E. Maurer and G. Pfleiderer

On the Possible Relation between Morphology and Precursors of the Crystallities in Calcified Tissues F. C. M. Driessens, R. A. Terpstra, P. Bennema, J. H. M. Wöltgens, and R. M. H. Verbeeck

916

In the Search for New Anticancer Drugs, XXI. Spin Labeled Nitrosoureas

G. Sosnovsky, S. W. Li, and N. U. M. RaO

Transmission of Hormonal Imprinting in Tetrahymena Cultures by Intercellular Communication

G. CsabA and P. Kovács

932

MTD Calculations on Quantitative Structure-Activity Relationships of Steroids Binding to the Progesterone Receptor

M. Bohl, Z. Simon, A. Vlad, G. Kaufmann, and

K. PONSOLD

935

Synthesis of Heat Shock Proteins during Amino Acid or Oxygen Limitation in Bacillus subtilis rel $A^{+}$and relA (In German)

M. Hecker, A. Richter, A. Schroeter, L. Wöl-FEL, and F. MACH

Sexual Pheromones and Related Egg Secretions in Laminariales (Phaeophyta)

I. Maier, D. G. Müller, G. Gassmann, W. BoLAND, and L. JAENICKE

948

Comparison of Dufour Gland Secretions of Two Species of Leptothorax Ants (Hymenoptera: Formicidae)

M. F. Ali, E. D. Morgan, A. B. Attygalie, and J. P. J. BILLEN 955 
Comparative Sex Pheromone Biosynthesis in the Obliquebanded Leafroller, Choristoneura rosaceana, and the Redbanded Leafroller, Argyrotaenia velutinana, Moths

St. P. Foster and W. L. Roelofs

961

Effect of Hydroxylamine Derivatives on Photorespiration in the Tobacco Aurea Mutant Nicotiana tabacum $\mathrm{Su} / \mathrm{su}$

G. H. Schmid, K. P. Bader, A. Radunz, C. J. van Assche, N. Reinier, and B. Courtiade 965

Estimation of the Extent of DNA Platination after Interaction of cis-DDP with DNA and Chromatin I. KulamowicZ and Z. WALTER 970

Reversed Light Reaction of the Screening Pigment in a Compound Eye Induced by Noradrenaline

A. Juse, G. Höglund, and K. Hamdorf 973

Light and Electron Microscopic Studies Regarding Cell Contractility and Cell Coupling in Light Sensitive Smooth Muscle Cells from the Isolated Frog Iris Sphincter

K. V. WOLF

Fluorescence Monitoring of Membrane Potentials: the Spatio-Temporal Resolution in Isolated Neurons of Helix pomatia

Th. KNÖPFEL and P. Fromherz

986

Growth Kinetics of the G2-Phase of Ehrlich Ascites Tumor Cells, Separated from Anaerobically Treated Asynchronous Cultures

C. Kroll, W. Kroll, and F. Schneider

Demonstration of Statistically Significant Correlations between 8 and $12 \mathrm{kHz}$ Atmosferics and Sudden Deafness

G. Ruhenstroth-Bauer, K. Mees, R. SandhaGEN, H. Baumer, and B. Filipiak

999

\section{Notes}

$\gamma$-Decalactone, an Odoriferous Compound from the Male Butterfly, Lethe marginalis Motschulsky

N. Hayashi, H. Kawaguchi, A. Nishi, and H. KOMAE

1001

The Phosphatidylinositol Species of Suspension Cultured Plant Cells

S. Heim and K. G. WAGNeR

1003
Are Small RNAs Associated with Crohn's Disease?

R. Pechan, H. Kunert, and H. J. Gross 1006

Inhibition of cAMP Phosphodiesterase by Some Phototherapeutic Agents

L. Bovalini, P. Lusini, S. Simoni, D. Vedaldi, L. Andreassi, F. Dall'Acqua, and P. Martellli

Report

Chimeric Genes - Their Contribution for Molecular Biology and Plant Breeding (In German)

H.-H. Steinbiss and J. Schell

1011

Contents of Number $9 / 10$

\section{Original Communications}

Terpenoids from a Black Sea Bryozoan Conopeum seuratum

P. Hadjeva, S. Popov, B. Budevska, A. DyulGEROV, and S. ANDREEV

1019

Thin Layer Chromatographic and Infra Red Spectral Evidence for the Presence of Phosphonolipids in Cicada oni

M. C. Moschidis

1023

Adnexal Glands Chemistry of Messor ebeninus Forel (Formicidae: Myrmicinae)

M. Coll, A. Hefetz, and H. A. Lloyd

1027

A Novel Caffeic Acid Derivative and Other Constituents of Populus Bud Excretion and Propolis (Bee-Glue)

E. Wollenweber, Y. Asakawa, D. Schillo, U. LehMANN, and H. Weigel

1030

Polyunsaturated Pheromones: Semi-Synthesis of $(Z, Z)-6,9$-Alkadienes and $(Z, Z, Z)-3,6,9$-Alkatrienes from Naturally Occurring Fatty Acids

H. K. Mangold, H. Becker, and E. Schulte

NMR Spectra of Flavone Di-C-glycosides from Apometzgeria pubescens and the Detection of Rotational Isomerism in 8-C-Hexosylflavones K. R. Markham, R. Mues, M. Stoll, and H. D. ZINSMEISTER

1039 


\title{
Stereochemistry of Two Hydroxybiflavanonols from Garcinia cola Nuts
}

\author{
Johann Sonnenbichler and Ifeanyi Madubunyi \\ Max-Planck-Institut für Biochemie, Am Klopferspitz, \\ D-8033 Martinsried, Bundesrepublik Deutschland \\ Hugo Scheer \\ Botanisches Institut der Universität München, Menzingerstraße 67. \\ D-8000 München. Bundesrepublik Deutschland \\ Z. Naturforsch. 42c, 855-857 (1987); received March 30/May 18. 1987 \\ Biflavanonol, Stereochemistry, Atropisomer, 'H NMR, Circular Dichroism \\ The absolute configuration of two hydroxybiflavanonols from Garcinia cola nuts have been \\ determined by $\mathrm{CD}$ and $500 \mathrm{MHz}{ }^{1} \mathrm{H}$ NMR spectroscopy. Additionally the occurrence of atrop- \\ isomers at room temperature as the consequence of rotational hindrance in the molecules could \\ be demonstrated.
}

\section{Introduction}

In 1971 Jackson et al. [1] elucidated the structures of two biflavanonols from Garcinia buchananii Baker using UV, IR and ${ }^{1} \mathrm{H}$ NMR spectroscopy. Cotterill and Scheinmann [2] isolated the same compounds from the nuts of Garcinia cola Heckel in 1978. Both compounds exhibit antihepatotoxic properties [3]. Very recently [4] we investigated in detail the biochemical mechanism of action of these drugs.

Each of the molecules contains four asymmetric carbon atoms suggesting the possibility of different configurations. The stereochemistry of the molecules, however, has not been investigated up to now. Using $500 \mathrm{MHz}{ }^{1} \mathrm{H}$ NMR spectroscopy at different temperatures and circular dichroism studies we analyzed the absolute configuration of the described biflavanonols and report here the occurrence of both molecules as atropisomers.

\section{Experimental}

The Garcinia biflavanonols were isolated from defatted Garcinia cola nuts by extraction with ethanol followed by elution of the dried and powdered ethanol extract with ethylacetate. Then by column chromatography on Kieselgel 60 (Merck) two major fractions were obtained with a) dichloromethanmethanol (14:9) saturated with water, b) chloroform-methanol-water $(64: 50: 10)$. This second fraction was further separated into 14 fractions by

Reprint requests to Prof. Dr. J. Sonnenbichler.

Verlag der Zeitschrift für Naturforschung, D-7400 Tübingen $0341-0382 / 87 / 0700-0855 \$ 01.30 / 0$ preparative thin-layer chromatography on Kieselgel $60 \mathrm{~F}_{254}$ (Merck) in chloroform-acetone-formic acid (9:2:1). The compounds with $R_{\mathrm{F}}$ values 0.15 and 0.25 represent an octahydroxy- and a heptahydroxybiflavanonol which show decomposition at $217^{\circ} \mathrm{C}$ and $200{ }^{\circ} \mathrm{C}$, respectively. If the ethylacetate extract was fractionated by thin-layer chromatography in different solvents avoiding chloroform and acids, the same compounds could be isolated. This indicates that the biflavanonoles are not products of a dimerization reaction during isolation.

The structures were analyzed by UV, MS and NMR spectroscopy.

The NMR spectra were recorded with a Bruker AM-500 spectrometer at different temperatures between $20^{\circ} \mathrm{C}$ and $90^{\circ} \mathrm{C}$. The $\mathrm{CD}$ spectra were measured in methanol at $25{ }^{\circ} \mathrm{C}$ with a Jobin-Yvon Dichrograph Mark IV in $0.2 \mathrm{~mm}$ concentrations.

\section{Results and Discussion}

After isolation of two biflavanonols from Garcinia cola nuts the structures of the purified compounds could be identified by UV, MS and NMR spectroscopy as $2,2^{\prime}, 3,3^{\prime}$-tetrahydro- $3^{\prime}, 5,5^{\prime}, 7,7^{\prime}$-pentahydroxy-2,2'-bis(4-hydroxyphenyl)-3, $8^{\prime}$-bi-1-4 H-benzopyran-4,4'-dion(I) and $2^{\prime}$-(3,4-dihydroxyphenyl)$2,2^{\prime}, 3,3^{\prime}$-tetrahydro- $3^{\prime}, 5,5^{\prime}, 7,7^{\prime}$-pentahydroxy-2-(4hydroxyphenyl)-3, $8^{\prime}$-bi-4 H-1-benzopyran-4,4'$\operatorname{dion}(\mathbf{I I})$.

The CD spectra (Fig. 1) show a Cotton-Effect at $290 \mathrm{~nm}(-)$ and $330 \mathrm{~nm}(+)$. By comparing the numerous data of Gaffield [5] for flavonoids with the Cotton-Effect of our compounds it can be deduced that both Garcinia biflavanonols have $S$-configura- 


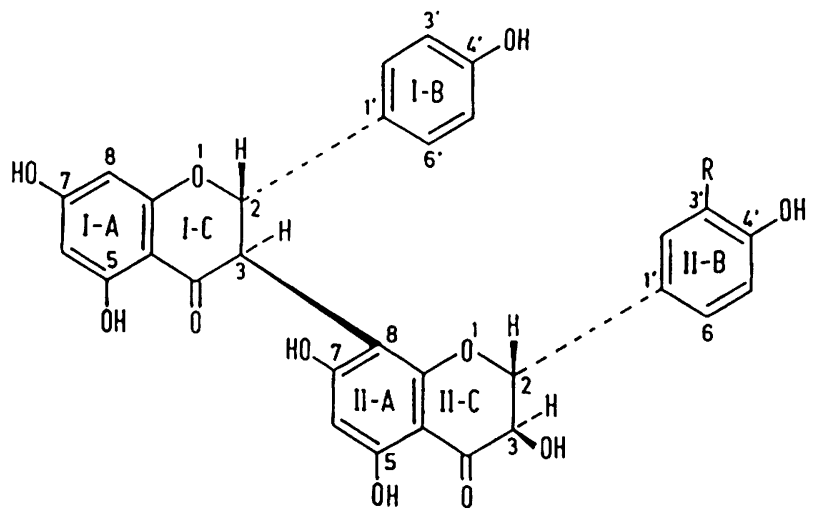

I $(\mathrm{R}=\mathrm{H}): 2,2^{\prime}, 3,3^{\prime}$-Tetrahydro-3',5, $5^{\prime}, 7,7^{\prime}$-pentahydroxy2,2'-bis(4-hydroxyphenyl)-3,8' -bi-1-4 H-benzopyran-4, $4^{\prime}$ dion.

II $(\mathrm{R}=\mathrm{OH}): 2^{\prime}-(3,4-$ Dihydroxyphenyl $)-2,2^{\prime}, 3,3^{\prime}$-tetrahydro-3', 5. 5',7,7'-pentahydroxy-2-(4-hydroxyphenyl)-3, $8^{\prime}$ bi-4H-1-benzopyran-4,4'-dion. tion at carbon I-C2 and $R$-configuration at carbon II-C2, according to the nomenclature of CahnIngold-Prelog [6].

The NMR data of $\mathbf{I}$ are listed in Table I. (Because of high analogy, the NMR data of II have been omitted in this short communication.) The coupling constants of the protons at I-C2 to I-C $3(J=12.1 \mathrm{~Hz})$ as well as $\mathbf{I I}-\mathrm{C} 2$ to $\mathbf{I I}-\mathrm{C} 3(J=11.6 \mathrm{~Hz})$ respectively manifest trans-positions of the hydrogens. Consequently we propose a $2 S 3 R$ configuration for the flavanone part and a $2 R 3 R$ configuration for the flavanonol part of the molecules, as shown in the formula.

In the NMR spectrum at $20^{\circ} \mathrm{C}$ it is remarkable that all resonances for the phenolic and alcoholic protons appear each with half intensity at double positions (Table I). This is also the case for the protons at carbons I-A 6, I-A 8, I-C2, I-C 3, II-C 2 and II-C 3 . This observation indicated a 1:1 mixture of

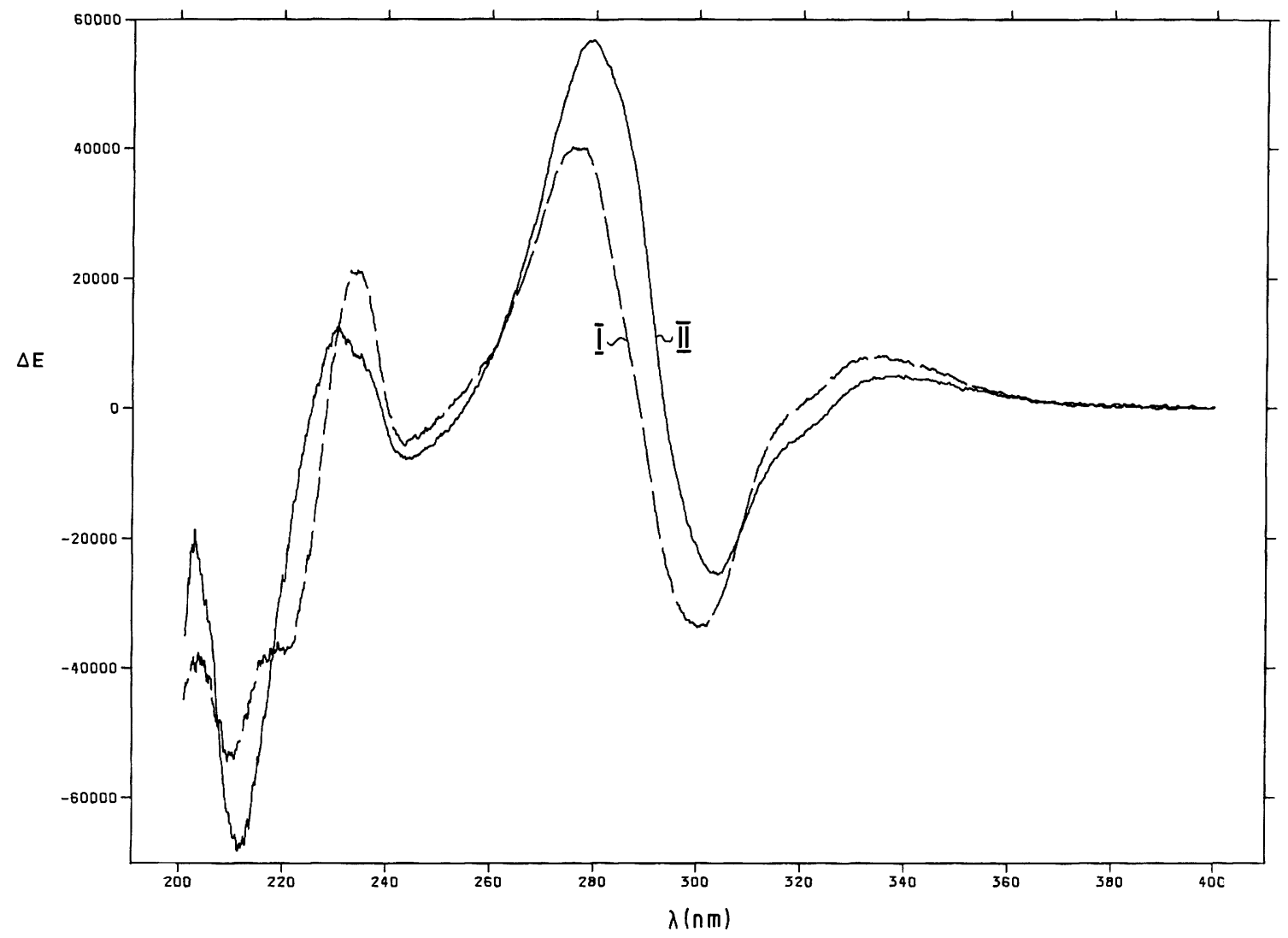

Fig. 1. CD spectra of I and II at $0.2 \mathrm{~mm}$ concentrations in methanol at $25^{\circ} \mathrm{C}$. 
Table I. NMR data of $\mathbf{I}$ at $20^{\circ} \mathrm{C}$ in $\mathrm{CDCl}_{3}$.

\begin{tabular}{|c|c|c|c|}
\hline Protons & ppm-Values & Number & Coupling constant \\
\hline I-A 6 & $* 5.83 / 5.78$ & 1 & \\
\hline I-A 8 & $* 5.97 / 5.87$ & 1 & \\
\hline II-A 6 & 5.91 & 1 & \\
\hline I-B 2' & 6.85 or 6.65 & 1 & $\mathrm{~d}(J=8.1 \mathrm{~Hz})$ \\
\hline I-B 3' & 7.17 & 1 & $\mathrm{~d}(J=8.1 \mathrm{~Hz})$ \\
\hline I-B 5' & 7.17 & 1 & $\mathrm{~d}(J=8.1 \mathrm{~Hz})$ \\
\hline I-B6' & 6.65 or 6.85 & 1 & $\mathrm{~d}(J=8.1 \mathrm{~Hz})$ \\
\hline II-B 2' & 6.65 or 6.75 & 1 & $\mathrm{~d}(J=8.1 \mathrm{~Hz})$ \\
\hline II-B 3' & 7.10 & 1 & $\mathrm{~d}(J=8.1 \mathrm{~Hz})$ \\
\hline II-B 5' & 7.08 & 1 & $\mathrm{~d}(J=8.1 \mathrm{~Hz})$ \\
\hline II-B 6 & 6.75 or 6.65 & 1 & $\mathrm{~d}(J=8.1 \mathrm{~Hz})$ \\
\hline I-C2 & * $5.65 / 5.32$ & 1 & $\mathrm{~d}(J=12.1 \mathrm{~Hz})$ \\
\hline I-C3 & $* 4.42 / 4.64$ & 1 & $\mathrm{~d}(J=12.1 \mathrm{~Hz})$ \\
\hline II-C2 & $* 5.14 / 4.97$ & 1 & $\mathrm{~d}(J=11.6 \mathrm{~Hz})$ \\
\hline II-C3 & * 4.22/3.98 & 1 & $\operatorname{dd}(J=11.6 / 6.0 \mathrm{~Hz})$ \\
\hline
\end{tabular}

Phenolic OH's

\begin{tabular}{|c|c|c|}
\hline I-A 5 & & \\
\hline I-A 7 & * 12.30/12.17; & * 11.86/11.74; \\
\hline II-A 5 & * 11.23/10.87; & * $10.75 / 10.71$ \\
\hline II-A 7 & * $9.58 / 9.56$ & * $\quad 9.47 / 9.44$ \\
\hline I-B $4^{\prime}$ & & \\
\hline II-B $4^{\prime}$ & & \\
\hline Alcoholic $\mathrm{OH}$ & & \\
\hline II-C3 & $* 5.83 / 5.73$ & $\mathrm{~d}(J=6.0 \mathrm{~Hz})$ \\
\hline
\end{tabular}

* These protons appear at two different positions with equal intensities of $0.5 \mathrm{H}$ each and coalesce after heating to about $70{ }^{\circ} \mathrm{C}$ focussing at intermediate ppm values.

two very similar isomers. However, we did not succeed in separating isomers.

The CD curves of $\mathbf{I}$ and II display $S$-shaped features between $280 \mathrm{~nm}(+)$ and $305 \mathrm{~nm}(-)$ with a

[1] B. Jackson, H. D. Locksley, and F. Scheinmann, J. Chem. Soc. (Section C, Part III) 1971, 3791-3804.

[2] P. J. Cotterill and F. Scheinmann, J. Chem. Soc. Perkin Trans. I 1978, 532-539.

[3] M. M. Iwu, Experientia 41, 699-700 (1985).

[4] I. Madubunyi and J. Sonnenbichler, Biochem. Pharmacol., in preparation. zero value near the UV maximum of the molecules at $293 \mathrm{~nm}$. This indicates a strong excitonic coupling of both parts of the molecule. This behaviour is characteristic for biflavonoids with atropisomers [7]. Presumably this is the case due to hydrogen bonding between the carbonyl group at I-C 4 and the phenolic hydroxyl at II-A7 with the consequence that, at room temperature, the rotation of the $3-8$ bond is restricted. This proposal is in good agreement with the observed doubling of the NMR signals (Table I). As was to be expected the described doubled NMR signals disappear with increase in temperature and coalesce at $70{ }^{\circ} \mathrm{C}$ to single sharp resonances as a consequence of increased rotations around the $3-8$ bond. This behaviour is characteristic for atropisomers and is in good agreement with the rotational barriers visible in space filling models for the established structures of $\left(2 S, 2^{\prime} R, 3 R, 3^{\prime} R\right)-2^{\prime}$-(3,4-dihydroxy-

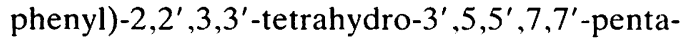
hydroxy-2-(4-hydroxyphenyl)-3,8'-bi-4H-1-benzopyran-4, $4^{\prime}$-dion(II) and $\left(2 S, 2^{\prime} R, 3 R, 3^{\prime} R\right)-2,2^{\prime} 3,3^{\prime}-$ tetrahydro-3', 5, 5', 7, $7^{\prime}$-pentahydroxy-2,2'-bis(4-hydroxyphenyl)-3, $8^{\prime}$-bi-1-4 H-benzopyran-4, $4^{\prime}$-dion(I).

Because of the differences in shift between the resonances of protons I-B2 and I-B 6, furthermore II-B 2 and II-B 6, additionally the bonds between rings I-B and I-C as well as rings II-B and II-C respectively must have hindered rotation at room temperature. This again is in good agreement with the atomic situation in space filling models of the molecules.

[5] W. Gaffield, Tetrahedron 26, 4093-4108 (1970).

[6] R. C. Cahn, C. K. Ingold, and V. Prelog, Experientia 12, $81-94$ (1956).

[7] H. Geiger and C. Quinn, in: The Flavonoids (B. J. Harborne, J. T. Mabry, and H. Mabry, eds.), p. 715 , Chapman and Hall Ltd., London 1975. 